\title{
KIẾN THỨC VÀ THỰC HÀNH TỰ CHĂM SÓC CỦA NGƯỜ' BẸNH SUY TIM MẠN TAI BẸNH VIẸN ĐA KHOA TỈNH QUẢNG NINH NĂM 2021
}

\author{
Đào Thị Phương ${ }^{1}$, Trần An Dương ${ }^{1}$ \\ ${ }^{1}$ Trường Cao đẳng Y tế Quảng Ninh
}

\section{TÓM TÁ́T}

Mục tiêu: Mô tả thực trạng kiến thức và thực hành tự chăm sóc của người bệnh suy tim mạn điều trị tại khoa Nội tim mạch - Bệnh viện Đa khoa tỉnh Quảng Ninh, năm 2021. Đối tượng và phương pháp nghiên cứu: Nghiên cứu mô tả cắt ngang được thực hiện trên 120 người bệnh được chẩn đoán suy tim mạn điều trị nội trú tại khoa Nội Tim mạch - Bệnh viện Đa khoa tỉnh Quảng Ninh. Kết quả: Kiến thức tự chăm sóc của người bệnh suy tim mạn tham gia nghiên cứu thấp với điểm trung bình kiến thức là 11,1 $\pm 2,1$ điểm trên tổng điểm 22, điểm thấp nhất là 6 điểm, cao nhất là 16 điểm, trong đó: tỷ lệ người bệnh có kiến thức ở mức khá là 40,0\%; tỷ lệ người bệnh có kiến thức ở mức trung bình là $60,0 \%$; không có người bệnh nào có kiến thức ở mức tốt và kém. Thực hành tự chăm sóc của người bệnh suy tim mạn được tính trên tổng điểm 100 cho mỗi nội dung: Thực hành về duy trì chăm sóc chỉ đạt 51,1 \pm 19,5 điểm và chỉ có 19,2\% người bệnh đạt duy trì chăm sóc; thực hành về quản lý chăm sóc chỉ đạt 49,4 \pm 19,8 điểm và chỉ có $22,5 \%$ người bệnh đạt quản lý chăm sóc; thực hành về sự tự tin đạt 50,5 土 16,1 điểm và chỉ có $17,5 \%$ người bệnh đạt tự tin trong tự chăm sóc. Kết luận: Người bệnh suy tim mạn đã có kiến thức và thực hành tự chăm sóc suy tim mạn nhưng chưa cao. Kết quả nghiên cứu cho thấy sự cần thiết phải có biện pháp nâng cao kiến thức và thực hành tự chăm sóc cho người bệnh suy tim mạn.

Từ khóa: Suy tim mạn, kiến thức, thực hành, tự chăm sóc.

\section{SELF-CARE KNOWLEDGE AND PRACTICES OF PATIENTS WITH CHRONIC HEART FAILURE AT QUANG NINH GENERAL HOSPITAL 2021}

\section{ABSTRACT}

Objective: To description of knowledge and practice of self-care of chronic heart failure patients treated at Cardiology Department - Quang Ninh General Hospital, 2021. Method: A cross-sectional study design was conducted among 120 patients with chronic heart failure hospitalized at the Cardiovascular Department of Quang Ninh General Hospital. Results: Self-care knowledge of patients with chronic heart failure participated in the study was low with the mean score of $11.1 \pm 2.1$ points out of the total 22 points, the lowest score was 6 points, and the highest score was 16 points, in which: the proportion

Tác giả: Đào Thị Phương

Địa chỉ: Trường Cao đẳng $Y$ tế Quảng Ninh

Email: daothiphuong.cyq@moet.edu.vn
Ngày phản biện: 05/9/2021

Ngày duyệt bài: 11/9/2021

Ngày xuất bản: 30/9/2021 
of patients with good knowledge was $40.0 \%$; the percentages of patients who had the good and average levels of self-care knowledge were $40.0 \%$ and $60.0 \%$, respectively. No one was at poor or perfect level of self-care knowledge. Self-care practice of patients with chronic heart failure was calculated on a total of 100 points for each subscale: Practice of maintenance of care only reaches $51.1 \pm 19.5$ points and only $19.2 \%$ of patients achieve a good level of care maintenance; practice of care management only achieved $49.4 \pm$ 19.8 points and only $22.5 \%$ of patients achieved care management level; practice on selfconfidence reached $50.5 \pm 16.1$ points and only $17.5 \%$ of patients achieved confidence in self-care level. Conclusion: The self-care knowledge and practice of patients with chronic heart failure was not enough. This result shows the need to improve self-care knowledge and practice for patients with chronic heart failure.

Keywords: Chronic heart failure, knowledge, practice, self-care.

\section{1. ĐẶT VẤN ĐÊ}

Suy tim là một hội chứng bệnh lý thường gặp trên lâm sàng [1], là một trong những nguyên nhân hàng đầu của tình trạng nhập viện điều trị, tỷ lệ mắc bệnh và tử vong cao ở nhiều nước. Theo thống kê, có khoảng 26 triệu người trên toàn thế giới mắc suy tim [2]. Tại Việt Nam, tuy chưa có một nghiên cứu chính thức về tỉ lệ mắc suy tim, nhưng theo tần xuất mắc bệnh của thế giới thì ước tính có khoảng 320.000 đến 1,6 triệu người bị suy tim [3]. Các nước phát triển dành $1-2 \%$ chi phí chăm sóc sức khoẻ cho khám và điều trị suy tim. Thực tế, hơn một nửa số trường hợp suy tim mạn tái nhập viện là do bệnh trầm trọng và là kết quả trực tiếp của việc tự chăm sóc kém [4]. Việc người bệnh suy tim, tự chăm sóc kém sẽ càng làm trầm trọng thêm tình trạng bệnh, tăng tỷ lệ tái nhập viện và tăng nguy cơ tử vong ở người bệnh suy tim mạn [5],[6]. Tại Việt Nam, người cao tuổi suy tim mạn có hành vi tự chăm sóc ở mức độ thấp chiếm từ $50,9 \%-83,6 \%[7]$.

Tại Bệnh viện Đa khoa tỉnh Quảng Ninh, trong những năm gần đây số người bệnh nằm điều trị nội trú tại khoa Nội Tim mạch vì suy tim khá cao (2018 khoảng 560 lượt người bệnh; năm 2019 khoảng 675 lượt) và thường tái nhập viện nhiều lần. Hiện nay, tại Quảng Ninh các nghiên cứu trên người bệnh suy tim thường tập trung vào lĩnh vực điều trị và chưa có nghiên cứu về lĩnh vực chăm sóc. Dưới góc độ điều dưỡng, với mong muốn tìm hiểu sâu về vấn đề tự chăm sóc của người bệnh suy tim, đặc biệt về kiến thức và thực hành tự chăm sóc của người bệnh trong thời điểm dịch Covid 19. Tạo cơ sở giúp cho lãnh đạo bệnh viện xây dựng những chương trình can thiệp hiệu quả, từ đó góp phần làm giảm tỷ lệ nhập viện, tử vong do suy tim gây ra, đồng thời góp phần mở rộng và cải thiện chất lượng dịch vụ chăm sóc y tế. Vì vậy chúng tôi tiến hành nghiên cứu đề tài: "Kiến thức và thực hành tự chăm sóc của người bệnh suy tim mạn tại Bệnh viện Đa khoa tỉnh Quảng Ninh, năm 2021" nhằm mục tiêu: mô tả thực trạng kiến thức và thực hành tự chăm sóc của người bệnh suy tim mạn điều trị tại khoa Nội tim mạch - Bệnh viện Đa khoa tỉnh Quảng Ninh, năm 2021.

\section{2. ĐÓI TƯỢNG VÀ PHƯƠNG PHÁP}

\section{1. Đối tượng nghiên cứu}

\subsubsection{Tiêu chuẩn lựa chọn}

Người bệnh được chẩn đoán suy tim mạn lần thứ 2 trở đi khi đó người bệnh đã có trải nghiệm về thực hành tự chăm sóc; người bệnh suy tim mạn nằm viện điều trị 
từ ngày thứ 3 trở đi khi các triệu chứng bệnh dần ổn định; người bệnh có đủ năng lực trả lời phỏng vấn, biết chữ; người bệnh tự nguyện tham gia nghiên cứu.

\subsubsection{Tiêu chuẩn loại trừ}

Người bệnh trong tình trạng nặng hoặc có thêm các bệnh lý nặng đang phải điều trị tích cực; người bệnh mắc bệnh mạn tính.

\subsection{Thời gian và địa điểm nghiên cứu}

Thời gian nghiên cứu: từ tháng 015/2021 tại khoa Nội Tim mạch Bệnh viện tỉnh Quảng Ninh.

2.3. Thiết kế nghiên cứu: Nghiên cứu mô tả cắt ngang.

2.4. Cỡ mẫu: Chọn mẫu toàn bộ

2.5 Phương pháp chọn mẫu: Chọn mẫu thuận tiện $n=120$

2.6. Công cụ và phương pháp thu thập số liệu: Trên cơ sở bộ câu hỏi gốc (bản tiếng Anh) về đánh giá kiến thức và thực hành tự chăm sóc trong suy tim thường được các tác giả nước ngoài sử dụng, bộ câu hỏi đã được dịch sang tiếng Việt và sử dụng bởi một số nghiên cứu trong nước. Hệ số Cronbach alpha cho cả phần kiến thức và thực hành của bộ công cụ đều đạt 0,8 . Phần kiến thức sử dụng bộ câu hỏi Atlanta Heart Failure Knowledge Test (AHFKT - V2), được phát triển bởi tác giả Carolyn
Miller Reilly, gồm 22 câu. Phần thực hành sử dụng bộ câu hỏi về hành vi tự chăm sóc Self-care of heart failure index (SCHFI), được phát triển bởi tác giả Riegel Barbara (2009) gồm 22 câu hỏi chia làm 3 lĩnh vực.

- Phương pháp thu thập số liệu:

Bước 1: Lấy danh sách NB

Bước 2: ĐTV giải thích về mục đích, ý nghĩa của nghiên cứu.

Bước 3: Phỏng vấn ĐTNC bằng phiếu điều tra.

\subsection{Tiêu chuẩn đánh giá các biến số} nghiên cứu

2.7.1. Đánh giá kiến thức: với mỗi câu hỏi về kiến thức, người bệnh trả lời đúng được 1 điểm, trả lời sai hoặc bỏ trống câu trả lời tính 0 điểm. Áp dụng cách phân loại kiến thức theo bộ câu hỏi Atlanta Heart Eailure Knowledge Test (AHFKT) và theo nghiên cứu của Trần Thị Ngọc Anh tại Viện tim mạch Việt Nam [8] cụ thể như sau: Từ 0 - 5 điểm: kiến thức kém; từ 6 -11 điểm: kiến thức trung bình; từ $12-17$ điểm: kiến thức khá; từ 18 - 22 điểm: kiến thức tốt.

2.7.2. Đánh giá thực hành: Mỗi lĩnh vực thực hành tự chăm sóc được tính riêng với phổ điểm từ 0 - 100 điểm. Áp dụng cách phân loại thực hành tự chăm sóc theo bộ câu hỏi Self-Care of Heart Failure Index (SCHFI) cụ thể như sau:

\begin{tabular}{|c|c|c|c|}
\hline Nội dung đánh giá & Cách tính điểm & $\begin{array}{c}\text { Không } \\
\text { đạt }\end{array}$ & Đạt \\
\hline $\begin{array}{l}\text { Thực hành duy trì chăm sóc } \\
\text { (từ } 10 \text { - } 40 \text { điểm) }\end{array}$ & (Tổng điểm duy trì chăm sóc -10) x 3,333 & \multirow{3}{*}{$\begin{array}{l}<70 \\
\text { điểm }\end{array}$} & \multirow{3}{*}{$\begin{array}{l}>=7 C \\
\text { điểm }\end{array}$} \\
\hline $\begin{array}{c}\text { Thực hành quản lý chăm sóc } \\
\text { (từ } 4 \text { - } 24 \text { điểm) }\end{array}$ & (Tổng điểm quản lý chăm sóc -4) x 5 & & \\
\hline $\begin{array}{c}\text { Sự tự tin } \\
\text { (từ } 6 \text { - } 24 \text { điểm) }\end{array}$ & (Tổng điểm sự tự tin - 6) x 5,56 & & \\
\hline
\end{tabular}

2.7.3. Phương pháp xử lý số liệu: Xử lý số liệu bằng phương pháp thống kê y học trên phần mềm SPSS 22.0 và bảng tần số và tỷ lệ phần trăm để mô tả các kết quả liên quan. 


\section{KÉT QUẢ}

\subsection{Thông tin chung của đối tượng nghiên cứu}

Bảng 1. Đặc điểm nhân khẩu học

\begin{tabular}{|c|c|c|c|}
\hline \multicolumn{2}{|c|}{ Đặc điểm nhân khẩu học } & SL & $\%$ \\
\hline \multirow{7}{*}{ Tuổi } & $<60$ tuổi & 32 & 26,7 \\
\hline & >=60 tuổi & 88 & 73,3 \\
\hline & Cao nhất & \multicolumn{2}{|c|}{88} \\
\hline & Thấp nhất & \multicolumn{2}{|c|}{22} \\
\hline & Trung bình $(X \pm S D)$ & \multicolumn{2}{|c|}{$65,4 \pm 12,6$} \\
\hline & Trung vị & \multicolumn{2}{|c|}{66,0} \\
\hline & Yếu vị & \multicolumn{2}{|c|}{60} \\
\hline \multirow{4}{*}{ Trình độ học vấn } & Tiểu học & 27 & 22,5 \\
\hline & Trung học cơ sở & 54 & 45 \\
\hline & Trung học phổ thông & 22 & 18,4 \\
\hline & Trung cấp, Cao đẳng, Đại học & 17 & 14,2 \\
\hline \multirow{4}{*}{ Nghề nghiệp } & Nông dân & 14 & 11,7 \\
\hline & Công nhân, viên chức & 36 & 30,0 \\
\hline & Nghỉ hưu & 64 & 53,3 \\
\hline & Tự do & 6 & 5,0 \\
\hline
\end{tabular}

Nhận xét: Người bệnh từ 60 tuổi trở lên chiếm 73,3\%, tuổi trung bình là 65,4 $\pm 12,61$ tuổi, tuổi xuất hiện nhiều nhất là 60 tuổi. Người bệnh có trình độ trung học cơ sở chiếm 45\%.

Bảng 2. Một số hướng dẫn và nguồn thông tin mà người bệnh đã nhận được

\begin{tabular}{|clcc|}
\hline & Nội dung & SL & $\%$ \\
\hline \multirow{3}{*}{ Hướng dẫn } & Sử dụng thuốc & 120 & 100 \\
& Chế độ ăn & 102 & 85,0 \\
& Lối sống & 45 & 37,5 \\
& Tự theo dõi và xử lý khi xuất hiện & 13 & 10,8 \\
& biểu hiện của bệnh & 0 & 0,0 \\
\hline Hành vi phòng ngừa & Nhân viên y tế & 120 & 100 \\
& Gia đình, bạn bè & 51 & 42,5 \\
& Tivi, internet & 41 & 34,2 \\
& Sách, báo, tờ rơi & 19 & 15,8 \\
\hline
\end{tabular}


Nhận xét: 13 người được hướng dẫn về cách tự theo dõi biểu hiện bệnh và biện pháp xử lý phù hợp khi bệnh diễn biến và đặc biệt không có người bệnh nào nhận được những hướng dẫn về hành vi phòng ngừa trong suy tim. Nguồn tin từ nhân viên y tế chiếm tỷ lệ cao nhất $100 \%$.

3.2. Thực trạng kiến thức và thực hành tự chăm sóc của người bệnh suy tim mạn

3.2.1. Kết quả nghiên cứu chung dựa trên điểm đánh giá kiến thức và thực hành Bảng 3. Điểm kiến thức và thực hành của người bệnh về tự chăm sóc

\begin{tabular}{|cccccc|}
\hline & Nội dung & \multicolumn{4}{c|}{ Điểm đạt } \\
& $\begin{array}{c}\text { Thấp } \\
\text { nhất }\end{array}$ & $\begin{array}{c}\text { Cao } \\
\text { nhất }\end{array}$ & $\begin{array}{c}\text { Trung } \\
\text { bình }\end{array}$ & $\begin{array}{c}\text { Độ lệch } \\
\text { chuẩn }\end{array}$ \\
\hline Kiến thức & 6 & 16 & 11,1 & 2,1 \\
\hline \multirow{2}{*}{ Thực hành } & Duy trì chăm sóc & 13,3 & 83,3 & 43,3 & 16,2 \\
& Quản lý chăm sóc & 10,0 & 85,0 & 49,3 & 19,7 \\
Sự tự tin & 16,6 & 88,9 & 51,0 & 19,5 \\
\hline
\end{tabular}

Nhận xét: Kiến thức và thực hành tự chăm sóc của người bệnh còn hạn chế: Kiến thức điểm trung bình kiến thức đạt 11,1 $\pm 2,1$ điểm; điểm trung bình thực hành duy trì chăm sóc là 43,3 $\pm 16,2$ điểm, điểm trung bình quản lý chăm sóc là 49,3 $\pm 19,7$ điểm, điểm trung bình sự tự tin là $51,0 \pm 19,5$ điểm.

\subsubsection{Kết quả nghiên cứu dựa trên phân loại kiến thức và thực hành}

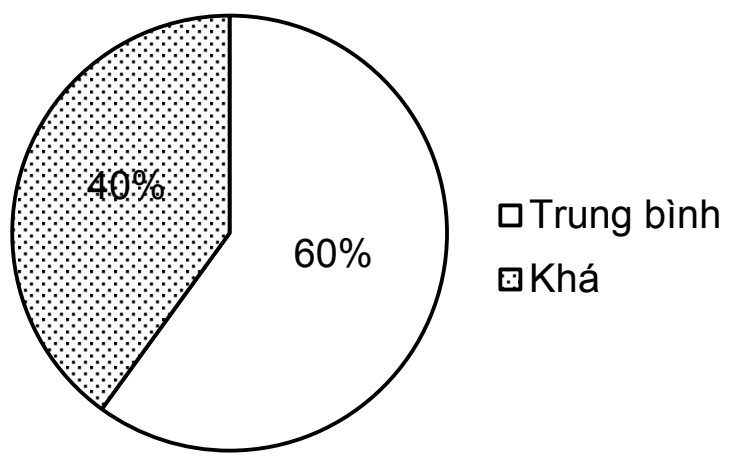

\section{Biểu đồ 1. Phân loại kiến thức tự chăm sóc}

Nhận xét: Có $60,0 \%$ người bệnh suy tim mạn có kiến thức về tự chăm sóc ở mức trung bình và 40,0\% người bệnh có kiến thức ở mức khá. 


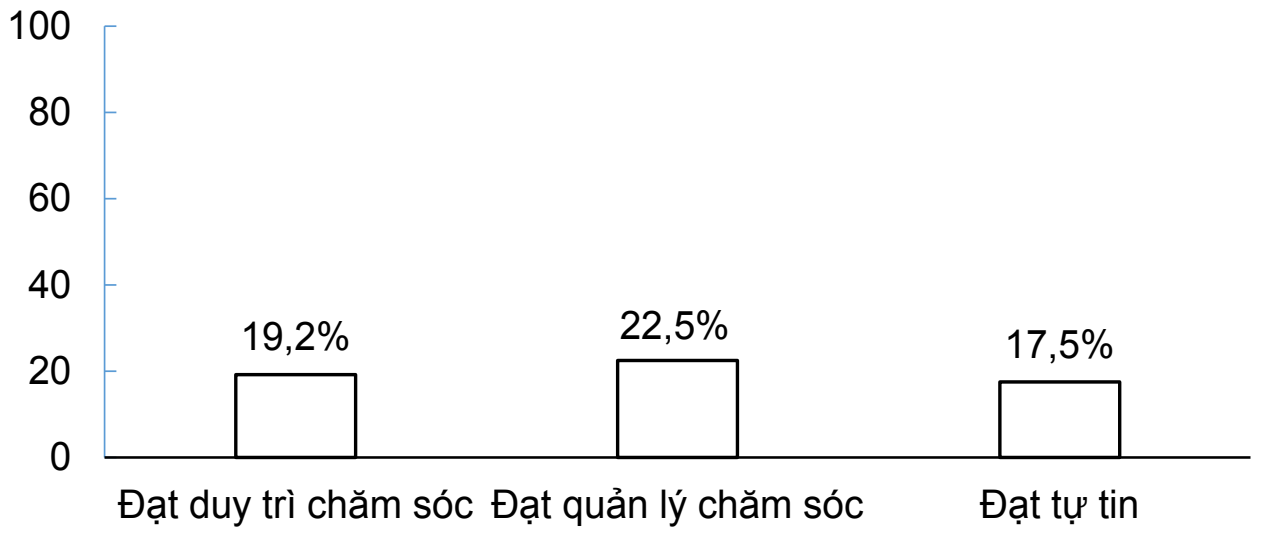

Biểu đồ 2. Phân loại thực hành tự chăm sóc

Nhận xét: Có 19,2\% người bệnh đạt duy trì chăm sóc; $22,5 \%$ người bệnh đạt quản lý chăm sóc và 17,5\% người bệnh đạt lĩnh vực tự tin trong tự chăm sóc.

\subsubsection{Kết quả nghiên cứu dựa trên các nội dung kiến thức}

Bảng 4. Kiến thức về bệnh suy tim của người bệnh $(n=120)$

\begin{tabular}{|c|c|c|c|c|}
\hline & Nội dung & Lựa chọn & SL & $\%$ \\
\hline \multirow{6}{*}{$\begin{array}{c}\text { Kiến thức về sử dụng } \\
\text { thuốc }\end{array}$} & \multirow{2}{*}{ Tác dụng thuốc lợi tiểu. } & Đúng & 70 & 58,3 \\
\hline & & Sai & 50 & 41,7 \\
\hline & \multirow{2}{*}{$\begin{array}{l}\text { Khi sử dụng thuốc lợi tiểu cần bổ sung } \\
\text { thêm Kali. }\end{array}$} & Đúng & 63 & 52,5 \\
\hline & & Sai & 57 & 47,5 \\
\hline & \multirow{2}{*}{$\begin{array}{l}\text { NB quên uống thuốc, cần uống ngay } \\
\text { khi nhớ ra. }\end{array}$} & Đúng & 31 & 25,8 \\
\hline & & Sai & 89 & 74,2 \\
\hline \multirow{6}{*}{$\begin{array}{l}\text { Kiến thức về } \\
\text { theo dõi cân nặng }\end{array}$} & \multirow[b]{2}{*}{ Kiến thức về tăng cân nặng } & Đúng & 69 & 57,5 \\
\hline & & & 51 & 425 \\
\hline & \multirow{2}{*}{ Tự theo dõi cân nặng hàng ngày } & Đúng & 47 & 39,2 \\
\hline & & Sai & 73 & 60,8 \\
\hline & \multirow{2}{*}{$\begin{array}{l}\text { Thời gian tốt nhất để cân là vào buổi } \\
\text { sáng. }\end{array}$} & Đúng & 36 & 30,0 \\
\hline & & Sai & 84 & 70,0 \\
\hline
\end{tabular}




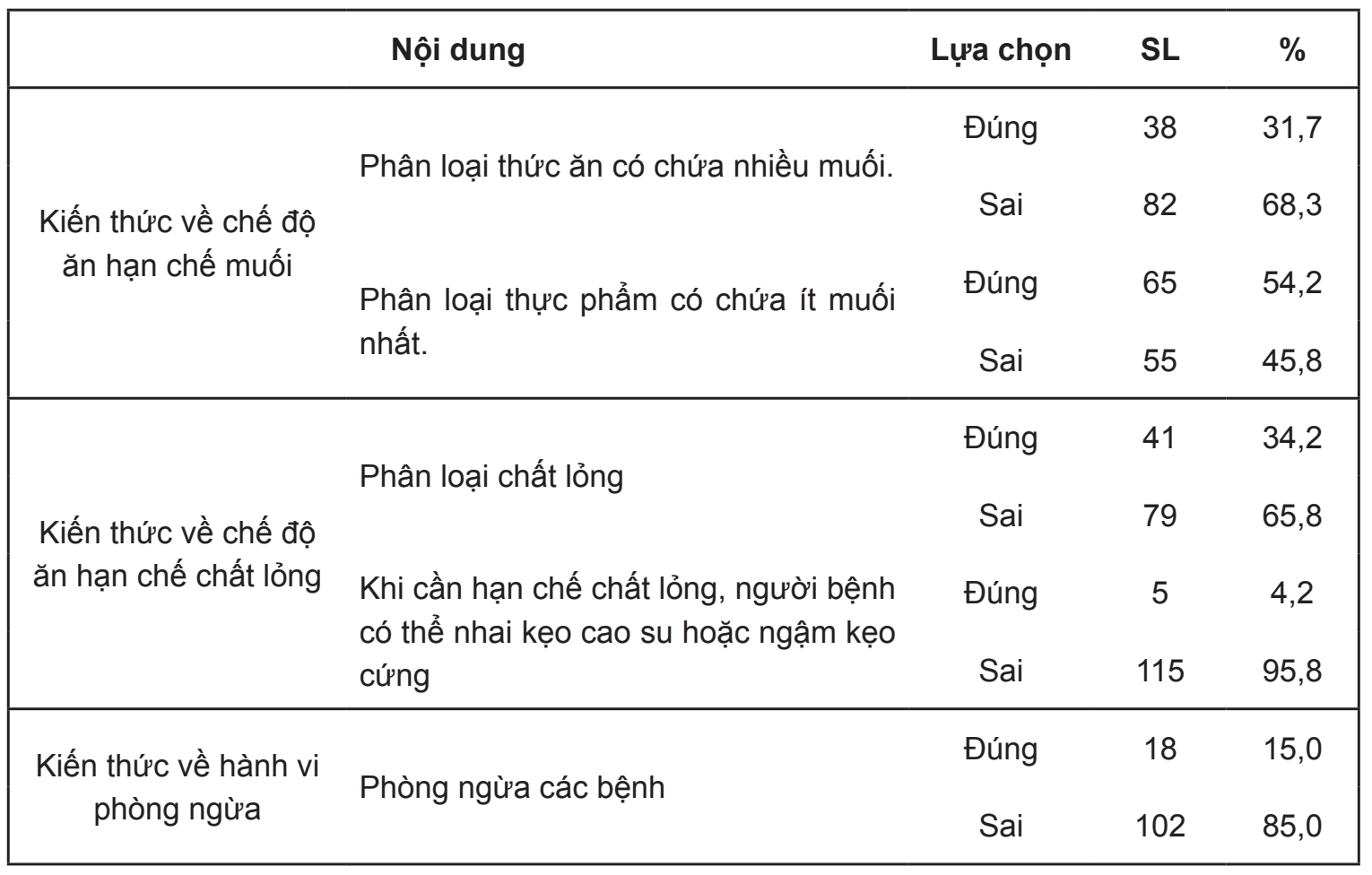

Nhận xét: Có 25,8\% người bệnh có kiến thức đúng khi người bệnh suy tim quên uống thuốc cần uống thuốc ngay khi nhớ ra. Người bệnh có kiến thức đúng về loại thức ăn có chứa nhiều muối chỉ đạt ở mức thấp $31,7 \%$. Kiến thức đúng về phân loại chất lỏng chỉ đạt $34,2 \%$. Nhận thức đúng khi cần hạn chế chất lỏng, người bệnh có thể nhai kẹo cao su hoặc ngậm kẹo cứng chiếm 4,2\%.Tỷ lệ thấp đạt 15\% người bệnh có kiến thức đúng về phòng ngừa các bệnh.

Bảng 5. Kiến thức đúng về một số hoạt động tụ̣ điều trị của người bệnh $(n=120)$

\begin{tabular}{|lcc|}
\hline \multicolumn{1}{|c}{ Nội dung } & SL & $\%$ \\
\hline Hạn chế ăn muối & 109 & 90,8 \\
\hline Hạn chế uống nhiều nước & 38 & 31,7 \\
\hline Không hút thuốc lá & 102 & 85,0 \\
\hline Không uống rượu bia hàng ngày & 89 & 74,2 \\
\hline Không bỏ thuốc suy tim khi thấy bệnh khoẻ hơn & 64 & 53,3 \\
\hline $\begin{array}{l}\text { Biết khi nào nên gọi NVYT hoặc đi khám bệnh khi có triệu } \\
\text { chứng suy tim }\end{array}$ & 114 & 95,0 \\
\hline
\end{tabular}

Nhận xét: Có 31,7\% người bệnh có kiến thức đúng về "Hạn chế uống nhiều nước", tỷ lệ người bệnh có kiến thức đúng về "Không bỏ thuốc suy tim khi thấy bệnh khỏe hơn" cũng chỉ chiếm 53,3\%. 


\subsubsection{Kết quả nghiên cứru dựa trên các nội dung thực hành}

Bảng 6. Kết quả thực hành Duy trì tự chăm sóc

\begin{tabular}{|c|c|c|c|}
\hline Duy trì chăm sóc & Lựa chọn & SL & $\%$ \\
\hline \multirow{4}{*}{ Theo dõi cân nặng } & Không hoặc hiếm khi & 62 & 51,7 \\
\hline & Thỉnh thoảng & 33 & 27,5 \\
\hline & Thường xuyên & 23 & 19,2 \\
\hline & Hàng ngày & 2 & 1,7 \\
\hline \multirow{4}{*}{ Theo dõi phù chân } & Không hoặc hiếm khi & 59 & 49,2 \\
\hline & Thỉnh thoảng & 32 & 26,7 \\
\hline & Thường xuyên & 17 & 14,2 \\
\hline & Hàng ngày & 12 & 10,0 \\
\hline \multirow{4}{*}{ Dự phòng bệnh } & Không hoặc hiếm khi & 47 & 39,2 \\
\hline & Thỉnh thoảng & 41 & 34,2 \\
\hline & Thường xuyên & 25 & 20,8 \\
\hline & Luôn luôn & 7 & 5,8 \\
\hline \multirow{4}{*}{ Chế độ ăn giảm muối } & Không hoặc hiếm khi & 24 & 20,0 \\
\hline & Thỉnh thoảng & 42 & 35,0 \\
\hline & Thường xuyên & 36 & 30,0 \\
\hline & Hàng ngày & 18 & 15,0 \\
\hline \multirow{4}{*}{$\begin{array}{l}\text { Quên uống } 1 \text { thuốc trong } \\
\text { trong đơn thuốc hàng ngày }\end{array}$} & Không hoặc hiếm khi & 20 & 16,7 \\
\hline & Thỉnh thoảng & 68 & 56,7 \\
\hline & Thường xuyên & 31 & 25,8 \\
\hline & Hàng ngày & 1 & 0,8 \\
\hline
\end{tabular}

Nhận xét: $51,7 \%$ người bệnh không hoặc hiếm khi theo dõi cân nặng; người bệnh không hoặc hiếm khi theo dõi phù là 49,2\%; hoạt động dự phòng, mức độ không hoặc hiếm khi là $39,2 \%$; tần xuất thực hiện ăn giảm muối mức độ hàng ngày là $15,0 \%$; người bệnh quên uống 1 thuốc trong trong đơn thuốc hàng ngày $0,8 \%$. 


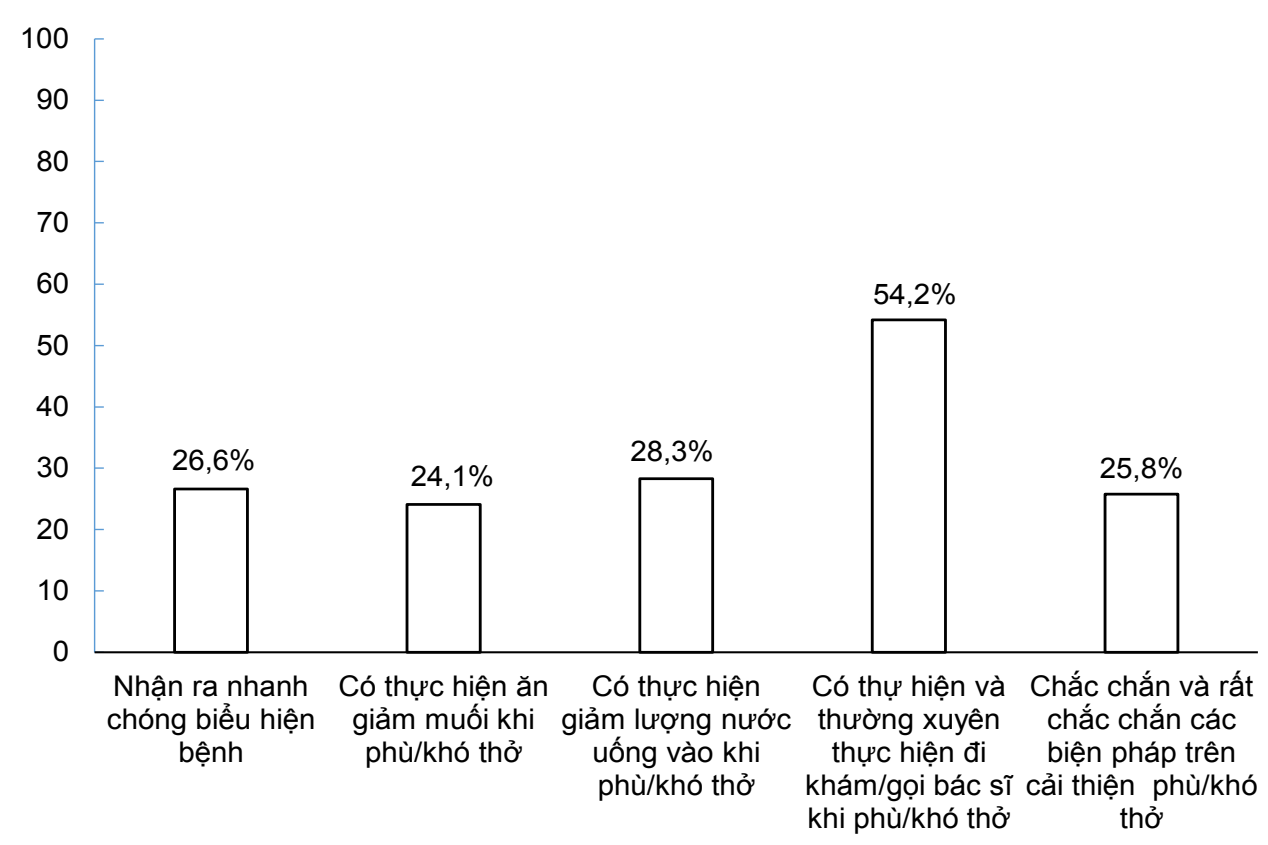

Biểu đồ 3. Thực hành "Quản lý chăm sóc"

Nhận xét: Thực hành trong việc nhận ra nhanh chóng các dấu hiệu của bệnh suy tim có $26,6 \%$ người bệnh. Có thực hiện ăn giảm muối và giảm lượng nước uống vào khi phù/ khó thở là $24,1 \%$ và $28,3 \%$.

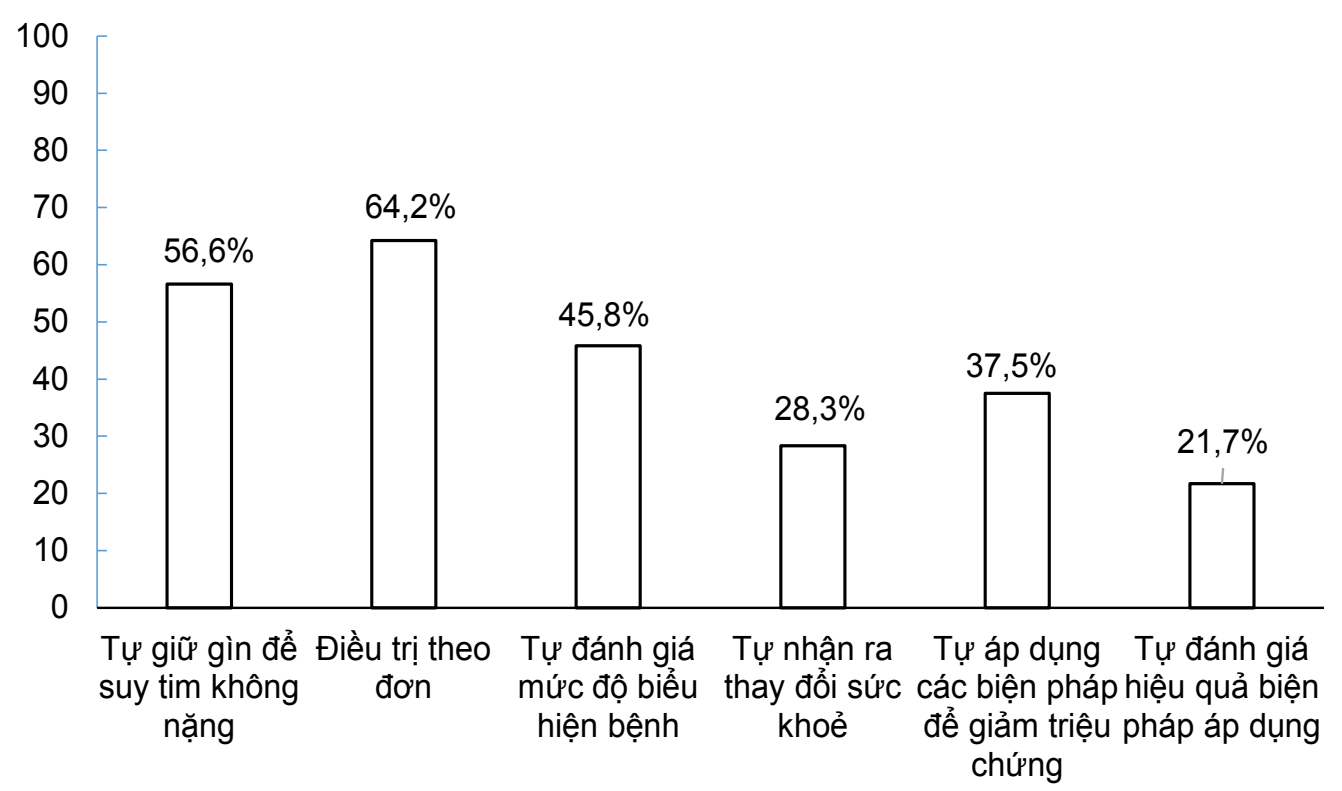

\section{Biểu đồ 4. Mức độ tự tin trong tụ̣ chăm sóc}

Nhận xét: Người bệnh "Tự tin" trong việc tự giữ giữ gìn để suy tim không nặng lên là 56,6\%; "Tự tin" trong việc đánh giá mức độ biểu hiện suy tim là 45,8\%; "Tự tin" trong việc nhận ra các thay đổi về sức khỏe là $28,3 \%$. 


\section{BÀN LUẤN}

\subsection{Thông tin chung của đối tượng nghiên cứu}

\subsubsection{Về tuổi}

Người bệnh có tuổi trung bình là $65,4 \pm$ 12,61 tuổi, người bệnh ít tuổi nhất là 22 tuổi và người bệnh nhiều tuổi nhất là 88 tuổi; tỷ lệ người cao tuổi chiếm tỷ lệ cao (73,3\%). Kết quả nghiên cứu này tương tự với kết quả nghiên cứu của Trần Thị Ngọc Anh (2016) [8] với độ tuổi trung bình trong nhóm nghiên cứu là 61,2 ะ 14,9 tuổi, người ít tuổi nhất là 23 tuổi và cao tuổi nhất là 89 tuổi.

\subsubsection{Về trình độ học vấn}

Trong nghiên cứu này, người bệnh có trình độ trung học cơ sở chiếm tỷ lệ cao nhất $(45 \%)$; trình độ đại học chiếm tỷ lệ thấp nhất (14,2\%). Như vậy, suy tim có mặt ở tất cả các trình độ học vấn. Điều này có điểm chung với nghiên cứu của Trần Thị Ngọc Anh (2016) [8], Phạm Thị Hồng Nhung (2019) [9] với người bệnh có trình độ trung học cơ sở chiếm tỷ lệ cao nhất lần lượt $41,0 \%$ và $51,1 \%$.

\subsubsection{Thông tin về việc người bệnh} nhận được một số hướng dẫn về tự chăm sóc

Trong nghiên cứu của chúng tôi, tất cả 120 người bệnh trước đó từng nằm viện điều trị suy tim đều cho biết họ đã nhận được một số hướng dẫn nhất định về điều trị và chăm sóc suy tim. Tuy nhiên, rất ít $(10,8 \%)$ người bệnh được hướng dẫn về cách tự theo dõi biểu hiện bệnh và biện pháp xử lý phù hợp khi bệnh diễn biến. Đặc biệt không có người bệnh nào nhận được những hướng dẫn về hành vi phòng ngừa trong suy tim. Qua nghiên cứu này, chúng tôi nhận thấy phần lớn người bệnh mong muốn được biết các thông tin về điều trị và chăm sóc sau điều trị như điều trị bằng thuốc, chế độ ăn uống, biến chứng... Đặc biệt hành vi phòng ngừa chưa được người bệnh đánh giá đúng tầm quan trọng trong điều trị bệnh.

\subsection{Thực trạng kiến thức và thực} hành tự chăm sóc của người bệnh suy tim mạn

\subsubsection{Thực trạng kiến thức tự chăm sóc của người bệnh suy tim mạn}

\section{Kiến thức chung}

Kiến thức chung của người bệnh suy tim mạn còn hạn chế với điểm trung bình đạt 11,1 $\pm 2,13$ điểm, điểm thấp nhất 6 , điểm cao nhất 16. Trong đó có $60,0 \%$ người bệnh suy tim mạn có kiến thức về tự chăm sóc ở mức trung bình và $40,0 \%$ người bệnh có kiến thức ở mức khá, không có người bệnh nào có kiến thức ở mức kém và tốt. Nghiên cứu của chúng tôi có điểm tương đồng với nghiên cứu Phạm Thị Hồng Nhung [9], kiến thức chung của người bệnh cũng chỉ đạt 10,41 \pm 3,54 điểm trên tổng số 22 điểm. Mặc dù nhiều người bệnh trong nghiên cứu của chúng tôi hay trong nghiên cứu Phạm Thị Hồng Nhung cũng đã nhận được một số hướng dẫn nhất định về tự chăm sóc nhưng chưa được đầy đủ, điều này có thể do người bệnh quên và có thể do các hướng dẫn trước đây chưa thường quy chưa hệ thống hoặc phương pháp hướng dẫn còn chưa phù hợp.

Kiến thức tự chăm sóc của người bệnh dưva trên các nội dung cụ thể

- Kiến thức về sử dụng thuốc: Người bệnh có kiến thức đúng về thuốc và sử dụng chưa cao. Cụ thể là chỉ có $58,3 \%$ người bệnh hiểu đúng về tác dụng của thuốc lợi tiểu, 52,5\% người bệnh hiểu đúng về việc khi sử dụng thuốc lợi tiểu phải bồ sung thêm Kali. Nghiên cứu Phạm Thị Hồng 
Nhung [9] có $37,8 \%$ người bệnh hiểu đúng về tác dụng của thuốc lợi tiểu, $20 \%$ người bệnh hiểu đúng về việc khi sử dụng thuốc lợi tiểu phải bổ sung thêm Kali. Ở nghiên cứu của Trần Thị Ngọc Anh [8] thì tỷ lệ này là $27,5 \%$ người bệnh hiểu đúng về việc khi sử dụng thuốc lợi tiểu phải bố sung thêm Kali. Như vậy thực trạng kiến thức sử dụng thuốc trong nghiên cứu của chúng tôi khả quan hơn so với 2 nghiên cứu trên. Tuy nhiên, tỷ lệ hiểu biết về tác dụng của thuốc lợi tiểu của nghiên cứu Wal M.H và cộng sự [11] thì cao hơn nghiên cứu của chúng tôi rất nhiều (84\%) [6].

- Kiến thức về theo dõi cân nặng: Người bệnh có nhận thức đúng về tăng cân nặng cơ thể chiếm tỷ lệ thấp chỉ đạt $57,5 \%$, người bệnh có nhận thức đúng tự theo dõi cân nặng hàng ngày chiếm $39,2 \%$ và người bệnh có nhận thức đúng về thời gian tốt nhất để cân vào buổi sáng chỉ chiếm $30,0 \%$. Cùng với vấn đề này ở nghiên cứu Phạm Thị Hồng Nhung [9] lần lượt là ( $33,3 \% ; 15,6 \% ; 41,1 \%)$. Nghiên cứu Trần Thị Ngọc Anh [8] với 19\% người bệnh có kiến thức đúng về tự theo dõi cân nặng và $46 \%$ người bệnh có kiến thức đúng về thời gian tốt nhất để cân là vào buổi sáng. Kết quả 3 nghiên cứu này cho thấy kiến thức về theo dõi cân nặng còn thấp nhìn chung chưa vượt quá $50 \%$ cho thấy việc tư vấn GDSK về theo dõi cân nặng ở Việt Nam chưa được thật sự chú trọng. Người bệnh chưa được hiểu rõ về lý do phải theo dõi cân nặng hàng ngày, chưa được hướng dẫn cách theo dõi cân nặng đúng cách.

- Kiến thức về chế độ ăn hạn chế muối: Kiến thức về chế độ ăn giảm muối của người bệnh trong nghiên cứu của chúng tôi còn chưa tốt. Cụ thể là người bệnh có kiến thức đúng về loại thức ăn có chứa nhiều muối và loại thực phẩm có chứa it muối nhất chiếm (31,7\%; 54,2\%). Kết quả này thấp hơn nghiên cứu của Trần Thị Ngọc Anh [8] với 2 tỷ lệ trên (52,5\%; 88,5\%). Lý giải cho sự khác biệt giữa hai nghiên cứu này có thể là do cỡ mẫu khác nhau (120 - 200), địa điểm nghiên cứu khác nhau và trình độ học vấn của người bệnh khác nhau trong 2 nghiên cứu.

- Kiến thức về hạn chế chất lỏng: Kiến thức về hạn chế chất lỏng của người bệnh trong nghiên cứu này còn chưa tốt. Có trên $50 \%$ người bệnh chưa có kiến thức đúng về phân biệt chất lỏng và hầu hết người bệnh $(95,8 \%)$ không biết kiến thức về "người bệnh suy tim đang phải cố gắng giới hạn lượng chất lỏng đưa vào, để giảm cơn khát nước người bệnh có thể nhai kẹo cao su hoặc ngậm kẹo cứng". Kết quả này tương tự với nghiên cứu của Trần Thị Ngọc Anh [8] với kết quả lần lượt hai vấn đề trên là (47,5\%; 96\%) và Phạm Thị Hồng Nhung [9] với tỷ lệ ( $34,4 \% ; 66,7 \%$ ). Như vậy qua kết quả 3 nghiên cứu tại địa dư Quảng Ninh, Hà Nội, Nam Định chúng tôi thấy được thực trạng chung của người bệnh suy tim về kiến thức hạn chế chất lỏng là rất thiếu.

- Kiến thức đúng về một số hoạt động tự điều trị: Kết quả nghiên cứu cho thấy, hầu hết người bệnh có kiến thức về một số hoạt động tự điều trị đạt mức tốt. Cụ thể có $90,8 \%$ người bệnh có kiến thức đúng về "Hạn chế ăn muối". Tuy nhiên, chỉ có 31,7\% người bệnh có kiến thức đúng về "Hạn chế uống nhiều nước" và $53,3 \%$ người bệnh có kiến thức đúng về "không bỏ thuốc suy tim khi thấy bệnh khỏe hơn". Kết quả chưa tốt này có thể do nhận thức về phân loại chất lỏng với $65,8 \%$ người bệnh không phân biệt được chất lỏng và $74,2 \%$ người bệnh không hiểu đúng về việc quên uống thuốc cần uống ngay khi nhớ ra (bảng 4). Ngoài ra, kết quả này cũng tương tự với 
nghiên cứu của Trần Thị Ngọc Anh [8] với 93,5\% người bệnh cố kiến thức đúng về "hạn chế muối trong chế độ ăn" và chỉ có 40,5\% người bệnh có kiến thức đúng về "hạn chế uống nhiều nước".

\subsubsection{Thực trạng thực hành tự chăm sóc của người bệnh suy tim mạn}

Thực hành tự chăm sóc: Điểm trung bình của 3 lĩnh vực trong tự chăm sóc còn thấp. Điểm trung bình duy trì chăm sóc, quản lý chăm sóc, sự tự tin lần lượt là

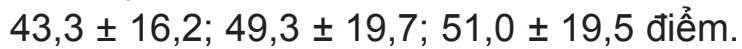
Trong đó chỉ có 19,2\% người bệnh đạt duy trì chăm sóc; $22,5 \%$ đạt quản lý chăm sóc và $17,5 \%$ người bệnh đạt tự tin trong tự chăm sóc. Trong nghiên cứu của chúng tôi có điểm tương đồng với nghiên cứu Phạm Thị Hồng Nhung [9] điểm trung bình cho ba lĩnh vực trên lần lượt là 41,5 $\pm 20,5 ; 35,5 \pm$ 15,$2 ; 50,4 \pm 16,1$. Mặc dù nhiều người bệnh trong nghiên cứu của chúng tôi hay trong nghiên cứu Phạm Thị Hồng Nhung cũng đã ý thức thực hiện tự theo dõi và tự xử trí các triệu trứng bệnh nhưng chưa tốt. Do đó, cần thiết phải có biện pháp thay đổi hành vi tự chăm sóc mục đích cải thiện sức khoẻ qua đó giảm tái nhập viện và nâng cao chất lượng cuộc sống cho người bệnh.

\section{Thực hành duy trì chăm sóc:}

- Hành vi tự theo dõi cân nặng: Thực hành của người bệnh về tự theo dõi cân nặng chưa tốt với trên một nửa số người bệnh $(51,7 \%)$ không hoặc hiếm khi theo dõi cân nặng và chỉ có 02 người bệnh $(1,7 \%)$ theo dõi cân nặng hàng ngày. Theo nghiên cứu của WalMH và cộng sự [11] có tới 35,0\% người bệnh theo dõi cân nặng hàng ngày. Lý giải cho sự khác biệt này có lẽ do người dân Việt Nam nói chung và người bệnh suy tim mạn ở Việt Nam nói riêng đều ít khi theo dõi cân nặng của mình.
- Hành vi theo dõi phù chân: Có 49,2\% người bệnh không hoặc hiếm khi theo dõi phù chân. Có 10,0\% người bệnh thực hiện theo dõi phù hàng ngày, tỷ lệ này cho thấy sự tương ứng giữa thông tin người bệnh nhận được khi nằm viện về tự theo dõi và xử lý khi xuất hiện biểu hiện của bệnh chỉ có 10,8\% (bảng 2).

- Hành vi ăn giảm muối: Tỷ lệ người bệnh thỉnh thoảng và hiếm khi ăn giảm muối là 55\% cao hơn trong nghiên cứu của Kiều Thị Thu Hằng [12] nghiên có kết quả 43\% người bệnh không thực hiện đúng về chế độ ăn giảm muối. Sự khác biệt này được lý giải có thể do điều kiện, môi trường sống của người bệnh trong nghiên cứu của chúng tôi sống tại khu vực vùng biển nên đảm bảo duy trì thường xuyên hành vi ăn nhạt tương đối là khó khăn.

- Hành vi quên uống một thuốc trong đơn thuốc hàng ngày: Có ít người bệnh $(16,7 \%)$ không hoặc hiếm khi quên uống thuốc, thậm chí có đến hơn một nửa số người bệnh $(56,7 \%)$ thỉnh thoảng quên uống thuốc. Lý giải cho điều này, nghiên cứa định tính về "Những khó khăn trong tự chăm sóc người bệnh suy tim tại Bệnh viện Đa khoa tỉnh Nam Định" của tác giả Phạm Thị Thu Hương [13] đã chỉ ra rằng: việc uống thuốc cũng gây khó khăn cho người bệnh. Do tác dụng của thuốc lợi tiểu "đêm dậy đi tiểu chục lần", cũng ảnh hưởng đến giấc ngủ của người bệnh rồi có người bệnh "về nhà không uống thuốc nữa" hoặc "sau khi ra viện, uống hết đơn thấy bình thường thì thôi".

Thực hành quản lý chăm sóc: việc nhận ra nhanh chóng các dấu hiệu của bệnh suy tim có $26,6 \%$ người bệnh. Có thực hiện ăn giảm muối và giảm lượng nước uống vào khi phù/khó thở là $24,1 \%$ và 28,3\%. Người bệnh đánh giá thực hiện các 
biện pháp quản lý tự chăm sóc chắc chắn và rất chắc chắn hiệu quả giúp cải thiện tình trạng phù, khó thở là $25,8 \%$. Như vậy có ít người bệnh $(26,6 \%)$ nhận ra nhanh chóng biểu hiện phù/khó thở là biểu hiện của bệnh suy tim. Lý giải cho điều này chúng tôi dựa theo nghiên cứu định tính của Phạm Thị Thu Hương: cũng có những người bệnh không thể nhận ra các triệu chứng dù đã bị bệnh nhiều năm, người bệnh nhầm lẫn với bệnh thận, đi khám mới biết là tim thậm chí có người bệnh cho rằng dấu hiệu nặng mặt là do ngủ nhiều [13]. Mặt khác có thể do người bệnh thỉnh thoảng hoặc không duy trì hành vi theo dõi phù (bảng 6) 45,9\% nên khi có triệu chứng xuất hiện ít có kinh nghiệm phát hiện nhanh.

Về sự tự tin: người bệnh tự tin trong tự giữ gìn để suy tim không nặng là $56,6 \%$; người bệnh tự tin trong việc nhận ra thay đổi sức khỏe là $28,3 \%$. Như vậy sự tự tin của người bệnh ở nghiên cứu còn thấp. Lý giải điều này cho nghiên cứu của chúng tôi có thể do thông tin kiến thức, thực hành tự chăm sóc của người bệnh đã được tiếp cận nhưng chưa được đồng nhất (từ gia đình, nguồn báo chí và nguồn ti vi, internet với tỷ lệ lần lượt là 42,5\%; 34,2\% và 15,8\% (Bảng 2); việc tự theo dõi và xử trí khi xuất hiện triệu chứng bệnh chỉ có $10,8 \%$ người bệnh được hướng dẫn. Vì vậy, người bệnh chưa đủ tự tin để thực hành tự chăm sóc bản thân một cách ưu việt nhất.

\section{KÉT LUẬN}

Kết quả nghiên cứu cho thấy, tỷ lệ người bệnh có kiến thức và thực hành tự chăm sóc còn thấp. Về kiến thức tỷ lệ khá là $40 \%$, trung bình là $60 \%$. Bên cạnh đó, chỉ có $10,8 \%$ người bệnh được hướng dẫn về cách tự theo dõi biểu hiện bệnh và biện pháp xử lý phù hợp khi bệnh diễn biến. Đặc biệt không có người bệnh nào nhận được những hướng dẫn về hành vi phòng ngừa trong suy tim. Về thực hành chỉ có $19,2 \%$ người bệnh đạt duy trì chăm sóc; $22,5 \%$ đạt quản lý chăm sóc và $17,5 \%$ người bệnh đạt tự tin trong tự chăm sóc. Do đó, các chương trình GDSK cần chú trọng hướng tới giáo dục về cách tự theo dõi bệnh, cung cấp kiến thức và hướng dẫn thực hành các biện pháp xử trí đối với mỗi tình huống diễn biến bệnh tại nhà hoặc cộng đồng trước khi đến cơ sở y tế hoặc nhận được sự trợ giúp của nhân viên y tế. Việc cung cấp giáo dục sức khỏe cho người bệnh cần được thực hiện hệ thống, định kì khoảng 2-3 tháng/ lần nhằm củng cố nhắc lại và bổ sung kiến thức, hướng dẫn thực hành mới về tự chăm sóc cho người bệnh.

\section{TÀI LIẸU THAM KHẢO}

1. Bộ Y Tế Việt Nam (2020), Quyết định số 1762/QĐ-BYT ngày 17 tháng 4 năm 2020 của Bộ Y tế về việc ban hành tài liệu chuyên môn Hướng dẫn chẩn đoán và điều trị suy tim mạn tính, < https://kcb.vn/vanban> truy cập ngày 08/7/2020.

2. Ponikowski P, Anker S. D, AlHabib K. F et al (2014). Heart failure: preventing disease and death worlwide. ESC Heart Fail, 1(1), p. 1-25.

3. Phạm Nguyễn Vinh và các cộng sự (2008). Khuyến cáo 2008 về các bệnh lý tim mạch và chuyển hóa, Khuyến cáo 2008 của Hội tim mạch học Việt Nam về chẩn đoán, điều trị suy tim, Nhà xuất bản y học, thành phố Hồ Chí Minh, tr.438-450.

4. Ross J. S, Chen J, Lin Z. Q et al (2009). Recent National Trends in Readmission Rates after Heart Failure Hospitalization. Circulation: Heart Failure, 3(1), pp. 97-103. 
5. Lam C. S. P (2015). Heart failure in Southeast Asia: facts and numbers. ESC Heart Fail, 2(2), pp. 46-49.

6. Spies C. D, Sander M, Stangl K et al (2001). Effects of alcohol on the heart Current Opinion in Critical Care, 7, pp. 337343.

7 Nguyễn Thị Hồng Hải (2017). Thực trạng hành vi tự chăm sóc ở người cao tuổi suy tim đang được điều trị tại bệnh viện Hữu Nghị Việt Nam Cu Ba - Đồng Hới Quảng Bình, Luận văn thạc sỹ Điều dưỡng, Trường Đại học Điều dưỡng Nam Định.

8. Trần Thị Ngọc Anh (2016). Kiến thức và thực hành tự chăm sóc ở nhà của người bệnh suy tim mạn tính tại viện Tim Mạch Việt Nam, Luận văn thạc sỹ y học, Trường Đại học Y Hà Nội.

9. Phạm Thị Hồng Nhung (2019). Đánh giá thay đổi kiến thức và thực hành tự chăm sóc của người bệnh suy tim mạn tại khoa
Nội Tim mạch Bệnh viện Đa khoa tỉnh Nam Định năm 2018. Tạp chí Khoa học Điều dưỡng, 2, tr. 22-27.

10. Ông Thị Mai Thương (2016). Thực trạng tiếp cận dịch vụ y tế của hộ nghèo ở thành thị. Tạp chí Khoa học - Công nghệ Nghệ An, 9, tr.21 - 26.

11. Wal M. H. L. V. D, Jaarsma T, Moser D. K et al (2006). Compliance in heart failure patients: the importance of knowledge and beliefs. Eur Heart J, 27(4), pp. 434-440.

12. Kiều Thị Thu Hằng (2011). Bước đầu ứng dụng thang điểm SCHFI đánh giá vấn đề tự chăm sóc của bệnh nhân suy tim được điều trị tại viện Tim mạch Việt Nam, Cử nhân y khoa, Trường Đại học y Hà Nội.

13. Phạm Thị Thu Hương và các cộng sự (2018). Những khó khăn trong tự chăm sóc ở người bệnh suy tim tại bệnh viện Đa khoa tỉnh Nam Định. Tạp chí khoa học Điều dương, 01 (01), tr. 53-60. 